\title{
Kemampuan Daya Hambat Bahan Aktif Beberapa Merek Dagang Hand sanitizer terhadap Pertumbuhan Staphylococcus aureus
}

\author{
Putri Srikartika ${ }^{1}$, Netti Suharti ${ }^{2}$, Eliza Anas ${ }^{3}$
}

\begin{abstract}
Abstrak
Hand sanitizer sebagai pembersih tangan antiseptik inovatif saat ini, sering menjadi alternatif pengganti cuci tangan dengan sabun dan air. Mencuci tangan dengan hand sanitizer merupakan salah satu cara memelihara kebersihan tangan agar terhindar dari penyakit yang disebabkan oleh flora normal di kulit yang berpotensi patogenik seperti bakteri Staphylococcus aureus. Tujuan penelitian ini adalah menilai kemampuan daya hambat beberapa merek dagang hand sanitizer terhadap pertumbuhan Staphylococcus aureus. Penelitian dilakukan dengan metode rancangan acak lengkap pada empat macam hand sanitizer dengan tiga kali pengulangan. Data diolah secara manual dan menggunakan analisis varians (ANOVA) dilanjutkan dengan uji pos-hoc dengan Tukey HSD dan independent $t$ test. Hasil penelitian menunjukkan bahwa bahan aktif hand sanitizer mampu mengurangi pertumbuhan Staphylococcus aureus secara signifikan. Perbedaan prosentase rerata pengurangan jumlah koloni pada waktu 30 detik berkisar antara 57,65\%-72,45\%, sedangkan pada waktu 1 menit berkisar 67,88\%-82,65\%. Hasil analisis menunjukkan perbedaan bermakna terhadap perlakuan, antar perlakuan dan waktu yang diujikan dengan nilai signifikasi $p<0,05$. Didapatkan hand sanitizer lebih efektif menghambat pertumbuhan pada waktu 1 menit daripada 30 detik. Hand sanitizer yang mengandung alkohol 70\% dan triklosan 0,05\% memiliki kemampuan daya hambat lebih baik terhadap pertumbuhan Staphylococcus aureus.
\end{abstract}

Kata kunci: bahan aktif, hand sanitizer, Staphylococcus aureus

\begin{abstract}
Hand sanitizer is one of the ways for maintaining the hand hygiene. Hand sanitizer as an innovative antiseptic product at this time, becomes an alternative hand washing with soap and water. It prevents the disease that can be caused by normal flora that potentially pathogenic bacterium such as Staphylococcus aureus. The objective of this study was to evaluate the inhibition ability of several trademarks hand sanitizer on the growth of Staphylococcus aureus. The research method used a completely randomized design in four kinds of hand sanitizer and three repetitions. Data processed manually and using analysis of variance (ANOVA) and followed by Post-Hoc test with Tukey HSD and also Independent T-Test.The results showed that the ingredients of hand sanitizer can reduce the growth of Staphylococcus aureus significantly. The differences on the percentage reduction of colonies in 30 seconds ranged between $57,65 \%-72,45 \%$, while the range in 1 minute was $67,88 \%-82,65 \%$. The analysis was also showed a real difference to the experiment, the combination of the experiment and the time of the experiment with significance value of $p<0.05$. Based on the result, hand sanitizers can inhibit the growth of Staphylococcus aureus effectively at 1 minute instead of 30 seconds. Hand sanitizer containing alcohol $70 \%$ and triclosan $0.05 \%$ has the better ability to inhibit the growth of Staphylococcus aureus.
\end{abstract}

Keywords: ingredients, hand sanitizer, Staphylococcus aureus 
Affiliasi penulis: 1. Prodi Profesi Dokter FK UNAND (Fakultas Kedokteran Universitas Andalas Padang), 2. Bagian Mikrobiologi FK UNAND, 3. Bagian Biologi FK UNAND.

Korespondensi: Putri Srikartika, Email: putrisrikartika@gmail.com, Telp: 08116684025

\section{PENDAHULUAN}

Tangan merupakan perantara paling sering terjadinya kontaminasi kuman terutama oleh mikroorganisme yang dapat berpindah tempat dan berpotensi patogenik, seperti kuman Staphylococcus aureus. Kuman tersebut dapat menyebabkan infeksi oportunistik (menyerang individu yang rentan) dan infeksi nosokomial dari rumah sakit, sehingga, kebersihan pada tangan sangat perlu dijaga agar terhindar dari hal demikian. ${ }^{1}$

Praktek mencuci tangan dengan sabun dan air adalah salah satu program kebersihan tangan untuk mengurangi risiko infeksi. Dalam kehidupan seharihari, kebiasaan dan menjaga kepatuhan terhadap praktik mencuci tangan dengan sabun tersebut menjadi sulit diatasi, terutama oleh orang yang memiliki aktivitas padat. Berdasarkan hal tersebut, maka banyak berkembang alternatif cuci tangan menggunakan pembersih tangan antiseptik yang dikenal dengan hand sanitizer. Ini adalah produk pembersih tangan tanpa air yang sering mengandung alkohol dan triklosan dan bekerja menghambat pertumbuhan bakteri. $^{2}$

Pada beberapa hasil penelitian terbukti bahwa hand sanitizer efektif mengurangi insidensi gangguan pencernaan, angka tidak masuk sekolah pada pelajar dan angka kesakitan pada beberapa mahasiswa, serta mengurangi penularan penyakit di dalam rumah tangga. $^{3}$

Saat ini penggunaan hand sanitizer semakin berkembang, mayoritas masyarakat membeli produk apa yang banyak diiklankan tidak melihat pada keefektifan suatu hand sanitizer seperti dalam konsentrasi berapa dan bahan apa saja yang ditambahkan untuk membuatnya cukup efektif. ${ }^{4}$

Tujuan penelitian ini adalah untuk menila kemampuan bahan aktif beberapa merek dagang hand sanitizer dalam menghambat pertumbuhan Staphylococcus aureus.

\section{METODE}

Penelitian ini merupakan studi eksperimental dengan metode rancangan acak lengkap. Sampel yang digunakan adalah gel hand sanitizer berjumlah empat buah. Penelitian dilaksanakan di Laboratorium Mikrobiologi Rumah Sakit Umum M. Djamil Padang dari bulan November sampai Desember 2014.

Penelitian ini menggunakan telapak tangan responden yang bersedia diperiksa jumlah bakteri pada daerah yang telah ditentukan baik sebelum dan setelah dilakukan perlakuan. Kondisi responden harus sehat dan tidak alergi terhadap sampel yang diuji.

Percobaan dilakukan pada dua waktu untuk mencari tahu apakah ada pengaruh waktu terhadap proses daya hambat hand sanitizer terhadap pertumbuhan Staphylococcus aureus dan waktu hambat yang lebih baik dari kedua waktu yang dipilih. Waktu yang diujikan yaitu 30 dan 60 detik.

Data diolah secara manual dan menggunakan analisis varians (ANOVA) dilanjutkan dengan tes PostHoc dengan Tukey HSD dan tes Independent T.

\section{HASIL}

Berdasarkan penghitungan yang dibaca pada colony counter, jumlah kuman Staphylococcus aureus sebelum diberi perlakuan oleh masing-masing hand sanitizer yang terdapat pada cawan petri berjumlah 258 koloni.

Setelah diberikan empat macam hand sanitizer, jumlah koloni Staphylococcus aureus tumbuh lebih sedikit daripada jumlah koloni sebelum diberi perlakuan tersebut baik pada waktu 30 detik maupun 1 menit. Jumlah koloni tersebut dapat dilihat pada hasil rata-rata pertumbuhan Staphylococcus aureus melalui uji statistik dengan analisis varians pada tabel yang tersaji berikut ini.

Tabel 1. Rerata jumlah koloni Staphylococcus aureus setelah perlakuan pada waktu 30 detik

\begin{tabular}{ccccc}
\hline $\begin{array}{c}\text { Hand } \\
\text { sanitizer }\end{array}$ & $\mathbf{n}$ & Rerata \pm SD & $\begin{array}{c}\mathbf{F} \\
\text { (Anova) }\end{array}$ & $\mathbf{p}$ \\
\hline A & 4 & $94,50 \pm 5,68$ & 28,193 & 0,000 \\
B & 4 & $83,50 \pm 8,58$ & & \\
C & 4 & $70,75 \pm 4,78$ & & \\
D & 4 & $109,25 \pm 4,78$ & & \\
\hline
\end{tabular}


Pada Tabel 1 dan 2, hasil analisis varians baik pada waktu 30 detik maupun 1 menit, memperlihatkan data signifikan dengan nilai 0,000 yang berarti $p<0,05$. Nilai tersebut menunjukkan adanya perbedaan yang bermakna pada rerata jumlah koloni Staphylococcus aureus terhadap tiap hand sanitizer yang diberikan.

Tabel 2. Rerata jumlah koloni Staphylococcus aureus setelah perlakuan pada waktu 1 menit

\begin{tabular}{ccccc}
\hline $\begin{array}{c}\text { Hand } \\
\text { sanitizer }\end{array}$ & $\mathbf{n}$ & Rerata \pm SD & $\begin{array}{c}\mathbf{F} \\
\text { (Anova) }\end{array}$ & $\mathbf{p}$ \\
\hline A & 4 & $71,00 \pm 5,35$ & 50,704 & 0,000 \\
B & 4 & $61,50 \pm 2,08$ & & \\
C & 4 & $44,75 \pm 5,31$ & & \\
D & 4 & $82,25 \pm 4,21$ & & \\
\hline
\end{tabular}

Pada waktu 30 detik, hasil penelitian dengan analisis lanjutan menggunakan metode post-hoc Tukey HSD menunjukkan adanya perbedaan bermakna antara tiap hand sanitizer, kecuali perbandingan antara pertumbuhan Staphylococcus aureus terhadap hand sanitizer A dengan pertumbuhan Staphylococcus aureus terhadap hand sanitizer B yang tidak berbeda nyata. Pada waktu 1 menit, semua hasil kombinasi perlakuan menunjukan nilai signifikansi $p<0,05$ yang berarti antara tiap hand sanitizer mempunyai perbedaan yang bermakna terhadap pertumbuhan Staphylococcus aureus.

Tabel 3. Persentase pengurangan koloni bakteri oleh bahan aktif hand sanitizer.

\begin{tabular}{|c|c|c|c|}
\hline $\begin{array}{c}\text { Hand } \\
\text { sanitizer }\end{array}$ & $\mathbf{n}$ & $\begin{array}{c}\text { Rerata } \\
\text { pengurangan } \\
(\%) \pm \text { SD (\%) }\end{array}$ & $\begin{array}{c}\text { Rerata } \\
\text { pengurangan } \\
(\%) \pm \text { SD (\%) }\end{array}$ \\
\hline & & 30 detik & 1 menit \\
\hline$A$ & 4 & $63,40 \pm 1,99$ & $72,35 \pm 2,05$ \\
\hline B & 4 & $67,53 \pm 3,35$ & $75,95 \pm 0,82$ \\
\hline $\mathrm{C}$ & 4 & $72,45 \pm 1,92$ & $82,65 \pm 2,23$ \\
\hline D & 4 & $57,65 \pm 1,78$ & $67,88 \pm 1,69$ \\
\hline
\end{tabular}

Besar daya hambat beberapa merek dagang hand sanitizer juga dapat diketahui dari rerata persentase pengurangan koloni Staphylococcus aureus. Hasil penelitian menunjukkan bahwa setiap hand sanitizer mampu menghambat pertumbuhan Staphylococcus aureus melalui pengurangan jumlah koloni dengan persentase pada waktu 30 detik berkisar antara 57,65\%-72,45\%, sedangkan pada waktu 1 menit berkisar antara 67,88\%-82,65\%. Hasil persentase pengurangan jumlah koloni tersebut dapat dilihat pada tabel berikut.

Pada Tabel 3 diatas, persentase pengurangan jumlah koloni lebih besar terjadi pada hand sanitizer tipe C, yaitu sebesar $72,45 \%$ pada waktu 30 detik dan $82,65 \%$ pada waktu 1 menit. Hasil tersebut juga dapat dilihat pada bagan dibawah ini.

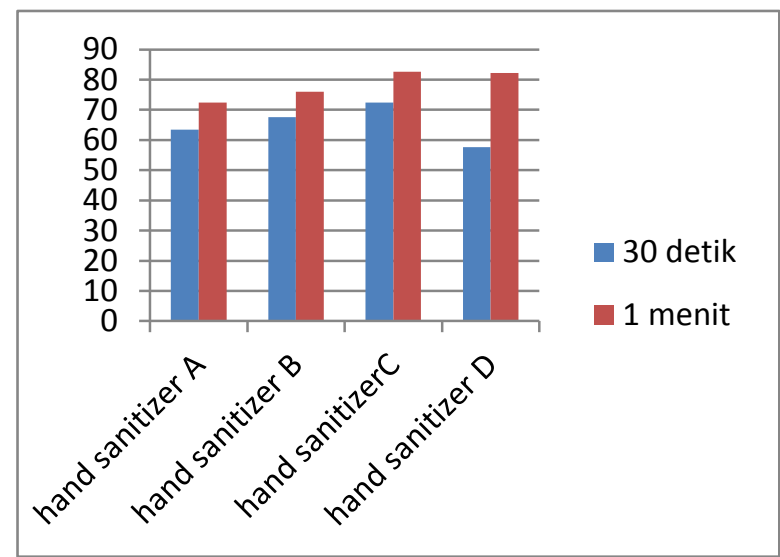

Gambar 1. Bagan persentase pengurangan koloni bakteri setelah perlakuan dari setiap kelompok pada waktu 30 detik dan 1 menit.

Berikut ini tabel hasil perbedaan waktu terhadap jumlah koloni Staphylococcus aureus setelah diberikan empat macam hand sanitizer.

Tabel 4. Hasil uji independen t-test waktu 30 detik dibandingkan dengan pada waktu 1 menit.

\begin{tabular}{ccccc}
\hline $\begin{array}{c}\text { Hand } \\
\text { sanitizer }\end{array}$ & Waktu & $\mathbf{n}$ & t-test & $\mathbf{p}$ \\
\hline A & 30 detik & 4 & 6,018 & 0,001 \\
& 1 menit & 4 & & \\
B & 30 detik & 4 & 4,982 & 0,002 \\
& 1 menit & 4 & & \\
C & 30 detik & 4 & 7,270 & 0,000 \\
& 1 menit & 4 & & \\
D & 30 detik & 4 & 8,416 & 0,000 \\
& 1 menit & 4 & & \\
\hline
\end{tabular}

Berdasarkan Tabel 4 diatas, hasil penelitian memperlihatkan semua nilai signifikasi berada pada $p>0,05$, sehingga dapat disimpulkan bahwa pada ke- 
empat hand sanitizer terdapat perbedaan bermakna antara waktu 30 menit dengan 1 menit terhadap jumlah koloni Staphylococcus aureus.

\section{PEMBAHASAN}

Berdasarkan penelitian yang telah dilakukan di Laboratorium Mikrobiologi Rumah Sakit Umum M. Djamil Padang, didapatkan bahwa masing-masing merek dagang hand sanitizer yang diujikan mempunyai kemampuan daya hambat terhadap pertumbuhan kuman Staphylococcus aureus. Uji statistik yang dilakukan memperjelas hasil pengolahan data dan menunjukkan nilai yang signifikan. Hasil penelitian juga membuktikan bahwa terdapat perbedaan besar daya hambat empat macam hand sanitizer melalui pengurangan jumlah koloni bakteri tersebut.

Perbedaan besar daya hambat pada hasil jumlah pertumbuhan bakteri dan hasil uji hipotesis pada tiap hand sanitizer disebabkan karena adanya kandungan bahan aktif yang berbeda dari masingmasing hand sanitizer yang diujikan. Pada merek dagang diketahui bahwa hand sanitizer $A$ mengandung bahan aktif alkohol dengan konsentrasi $60 \%$, hand sanitizer B mengandung alkohol $60 \%$ dan triklosan 0,05\%, hand sanitizer C hampir sama dengan hand sanitizer $\mathrm{B}$, namun bahan aktif yang terkandung berupa alkohol $70 \%$ dengan triklosan $0,05 \%$, chamomile extract $0,05 \%$, dan aloe vera $0,5 \%$ sedangkan hand sanitizer D konsentrasi alkoholnya lebih kecil yaitu sebesar $51 \%$ dan ditambah isopropyl alcohol sebesar $3 \%$.

Pada hasil penelitian, baik hand sanitizer A, B dan C mampu mengurangi jumlah pertumbuhan kuman dengan persentase lebih dari $60 \%$ pada waktu 30 detik dan pada waktu 1 menit persentase lebih dari $70 \%$. Hal tersebut dapat dikatakan cukup efektif dalam mengurangi pertumbuhan bakteri dibandingkan dengan hand sanitizer D yang persentasenya lebih kecil, yaitu lebih dari $50 \%$ pada waktu 30 detik dan lebih dari $60 \%$ pada waktu 1 menit.

Hasil tersebut sesuai dengan penelitian sebelumnya tentang analisis perbandingan cairan antiseptik pada pertumbuhan Staphylococcus epidermidis, bahwa kadar alkohol yang efektif sebagai antiseptik berkisar antara 60\% sampai 90\%, sedangkan kadar alkohol yang kurang dari $60 \%$ tidak dapat secara efektif membunuh bakteri atau virus yang terdapat pada tangan atau alat kesehatan lainnya. $^{1}$

Koloni Staphylococcus aureus lebih sedikit jumlahnya pada hand sanitizer produk B dan C. Hasil persentase pengurangan pertumbuhan bakteri tersebut juga menunjukkan bahwa kedua hand sanitizer tersebut menghasilkan nilai yang lebih besar dibandingkan hand sanitizer A dan D. Hasil ini bisa terjadi karena kedua pembersih tangan itu mempunyai konsentrasi alkohol yang lebih besar dan ditambah oleh bahan aktif yang mengandung triklosan.

Berlandaskan pada yang telah disebutkan diatas, dapat diketahui bahwa semakin besar konsentrasi alkohol hingga 90\%, maka semakin besar kemampuannya mengganggu proses metabolisme bakteri tersebut. Aktivitas triklosan diduga mampu mempengaruhi dinding sel mikroba sehingga integritas dinding sel bakteri terganggu dan mengakibatkan sel tersebut mengalami lisis. Triklosan efektif untuk bakteri baik Gram positif dan Gram negatif. ${ }^{5}$ Dengan demikian, kedua bahan aktif tersebut memperkuat besarnya daya hambat hand sanitizer terhadap pertumbuhan kuman.

Dalam pengolahan data, karena hand sanitizer C menunjukkan pengurangan lebih besar daripada hand sanitizer yang lain yaitu dengan persentase $72,45 \%$ pada waktu 30 detik dan $82,65 \%$ pada waktu 1 menit, maka dapat ditarik kesimpulan sementara bahwa hand sanitizer yang mengandung alkohol $70 \%$ dan triklosan 0,05\% lebih efektif daripada tiga macam hand sanitizer lain yang diujikan.

Hasil tersebut mendukung penelitian yang telah pernah dilakukan bahwa antiseptik yang mengandung kadar alkohol sebesar $70 \%$ akan lebih peka dan bekerja lebih cepat dalam mengendapkan protein dan menghancurkan membran lipid terutama pada stafilokokus daripada alkohol dengan konsentrasi 40$60 \%$. Cairan antiseptik yang mengandung alkohol $70 \%$ di kulit, dapat membunuh hampir $90 \%$ bakteri kulit karena bisa menembus dinding sel. ${ }^{6}$

Dilihat dari komposisi hand sanitizer $\mathrm{C}$, ternyata selain mengandung alkohol $70 \%$ dan triklosan sebagai 
antibakteri, hand sanitizer tersebut juga mengandung zat anti bakteri lain yaitu ekstrak khamomil dengan konsentrasi $0,5 \%$.

Pada penelitian sebelumnya menjelaskan ekstrak tersebut terbukti mampu menghambat pertumbuhan Staphylococcus aureus, Streptococcus mutans dan Streptococcus salivarius grup B. Ekstrak tersebut merupakan ekstrak dari tanaman khamomil dengan nama ilimiah Chamaemelum nobile yang banyak dimanfaatkan pada sabun, teh, obat anti alergi, anti inflamasi dan antiseptik. ${ }^{7}$ Secara empiris dapat disimpulkan bahwa ekstrak tersebut membantu kefektifan daya hambat bahan aktif hand sanitizer $\mathrm{C}$. Kombinasi bahan aktif tersebut menyebabkan hand sanitizer tersebut lebih efektif daripada hand sanitizer lain.

Adapun penghitungan waktu hand sanitizer bekerja pada penelitian, ternyata juga berpengaruh terhadap jumlah pengurangan koloni Staphylococcus aureus. Dalam hal ini, karena waktu yang diujikan adalah 30 detik dan 1 menit, sehingga pada kedua waktu tersebut, pertumbuhan koloni yang lebih banyak berkurang dibandingkan tanpa menggunakan hand sanitizer. Menurut United States Food and Drugs Administration (US FDA), dalam waktu 30 detik hingga 60 detik hand sanitizer sudah langsung dapat mengurangi jumlah kuman. ${ }^{8}$

Berdasarkan hasil pengamatan, jumlah koloni kuman pada 1 menit lebih sedikit dibandingkan pada waktu 30 detik. Hal tersebut mungkin terjadi karena dengan waktu 1 menit tersebut waktu kerja hand sanitizer akan lebih efektif dalam mendenaturasi dan mengkoagulasi protein. Pernyataaan ini didukung dari hasil uji analisis varians dengan metode post-hoc Tukey HSD yang menjawab bahwa daya hambat antara keempat hand sanitizer dapat berbeda nyata pada waktu 1 menit, sedangkan pada waktu 30 detik, pada hand sanitizer A dan B tidak berbeda secara nyata. Sejalan dengan pada penelitian sebelumnya yang menjelaskan bahwa pembersih tangan yang mengandung alkohol $60 \%$ akan melindungi tangan selama 1 atau 2 menit, sehingga dapat disimpulkan keefektifan hand sanitizer juga bergantung lamanya hand sanitizer tersebut dapat menghambat pertumbuhan kuman. ${ }^{9}$ Hasil uji statistik dengan independen $t$ test juga menunjukkan perbedaan bermakna pada kedua waktu tersebut.

Dari segi biaya, empat macam hand sanitizer memiliki kisaran harga yang berbeda. Hand sanitizer $\mathrm{A}$ dijual berkisar harga Rp. 10.000,- hingga Rp. 11.000,-, hand sanitizer B seharga Rp. 5.000,-, hand sanitizer C dengan harga rata-rata Rp. 8.000,- dan hand sanitizer D rata-rata seharga Rp. 11.000,-. Jika dilihat dari penghitungan harga dengan kemampuan hambat yang lebih baik, maka dapat dismpulkan bahwa harga tidak sejalan dengan kemampuan daya hambat hand sanitizer untuk melindungi tangan terutama terhadap pertumbuhan Staphylococcus aureus.

Hand sanitizer A dan D dengan kemampuan daya hambat kurang baik atau kurang efektif dalam menghambat pertumbuhan bakteri Staphylococcus aureus dijual dengan harga yang lebih mahal daripada hand sanitizer B dan C yang terbukti lebih efektif. Hal ini bisa disebabkan karena pengaruh promosi iklan dan yang diterima oleh masyarakat selama ini dengan kemampuan persuasi dari produsen merek dagang hand sanitiser $\mathrm{A}$ dan $\mathrm{D}$ tersebut sangat kuat dan banyak dilakukan, berbeda dengan hand sanitizer $B$ dan $\mathrm{C}$ yang tidak mendapat banyak perhatian dari masyarakat karena kurangnya promosi dari produsen produk inovatif tersebut.

Sejalan dengan penelitian sebelumya, bahwa mayoritas konsumen memilih hand sanitizer karena pengaruh iklan dan promosi dari televisi, keharuman, dan lokasi dimana produk hand sanitizer dijual. ${ }^{4}$

Pemikiran hand sanitizer mana yang lebih baik digunakan atau setidaknya yang benar digunakan tidak begitu sesuai dengan apa yang terjadi pada masyarakat. Hal ini perlu diluruskan dan dibantu dengan promosi serta pengaruh yang besar dari berbagai pihak agar dapat mengubah paradigma masyarakat terhadap cara pemilihan beberapa merek dagang hand sanitizer yang dijual dipasaran seperti melalui bahan aktif dan konsentrasinya serta penggunaan hand sanitizer yang lebih tepat.

\section{KESIMPULAN}

Hand sanitizer mampu menghambat pertumbuhan Staphylococcus aureus melalui pengurangan jumlah koloni dari bahan aktifnya. 
Persentase pengurangan jumlah koloni Staphylococcus aureus oleh hand sanitizer pada waktu 30 detik lebih baik dibandingkan pada waktu 1 menit.

Hand sanitizer mampu menghambat pertumbuhan Staphylococcus aureus lebih baik pada waktu 1 menit dibandingkan dengan waktu 30 detik.

Hand sanitizer yang mengandung alkohol $70 \%$ dan triklosan 0,05\% memiliki kemampuan daya hambat yang lebih baik terhadap pertumbuhan bakteri Staphylococcus aureus.

\section{UCAPAN TERIMA KASIH}

Terimakasih kepada semua pihak atas
masukan dan bimbingan dalam penyelesaian
penelitian ini.

\section{DAFTAR PUSTAKA}

1. Radji M, Herman S, Dessy A: Uji efektivitas antimikroba beberapa merek dagang pembersih tangan antiseptik. Majalah IImu Kefarmasian. 2007; 4:1-6.

2. Purnama DE, Eva N, Geisandra AP, Novia PA, Walidatul LM: Analisis perbandingan keefektifan beberapa merek dagang antiseptik hand sanitizer dalam menghambat pertumbuhan staphylococcus epidermidis. 2010;1:1-21.

3. White C, Kolble R, Carlson R, Lipson N, Dolan M, Ali $Y$, et al. The effect of hand hygiene on illness rate among students in university residence halls. Am J Infect Control; 2003;31:364-70.

4. Ramadhanti: Analisis perilaku konsumen produk pembersih tangan tanpa air (hand sanitizer). Bogor Agricultural University Scientific Repository. 2004; $1: 118$.

5. Rachmawati FJ, Shofyatul YT: Perbandingan angka kuman pada cuci tangan dengan beberapa bahan sebagai standarisasi kerja di laboratorium mikrobiologi fakultas kedokteran universitas islam indonesia. Logika. 2008;5(1):26-31.

6. Theodorus: Antiseptik-disinfektan. Dalam: Staf Pengajar Departemen Farmakologi Fakutas Kedokteran Universitas Sriwijaya. Kumpulan kuliah farmakologi. Palembang: EGC; 2010; hlm.163-7.

7. Saderi $H$, Owlia $P$, Hosseini $A$, Semiyari $H$ : Antimicrobial effects of chamomile extract and essential oil on clinically isolated porphyromonas gingivalis from periodonitis. Department Microbiology Faculty of Medicine, Shahed University. 2005. hlm.145-6.

8. Chen YC, Sheng WH, Wang JT, Chang SC, Lin $\mathrm{HC}$, Tien $\mathrm{KL}$, et al. Effectiveness and limitations of hand hygiene promotion on decreasing healthcare-associated infections. Pone Journal. 2011;10(3):13-71.

9. Philip JA: ESCRT factors restrict mycobacterial growth. Medical Education Journal. 2008; 105(8): 3070-5. 